Abstracta Iranica Abstracta Iranica

Revue bibliographique pour le domaine irano-aryen

Volume 40-41 | 2019

Comptes rendus des publications de 2017-2018

\title{
Turfanforschung (eds.). Zur lichten Heimat - Studien zu Manichäismus, Iranistik und Zentralasienkunde im Gedenken an Werner Sundermann
}

Thomas Jügel

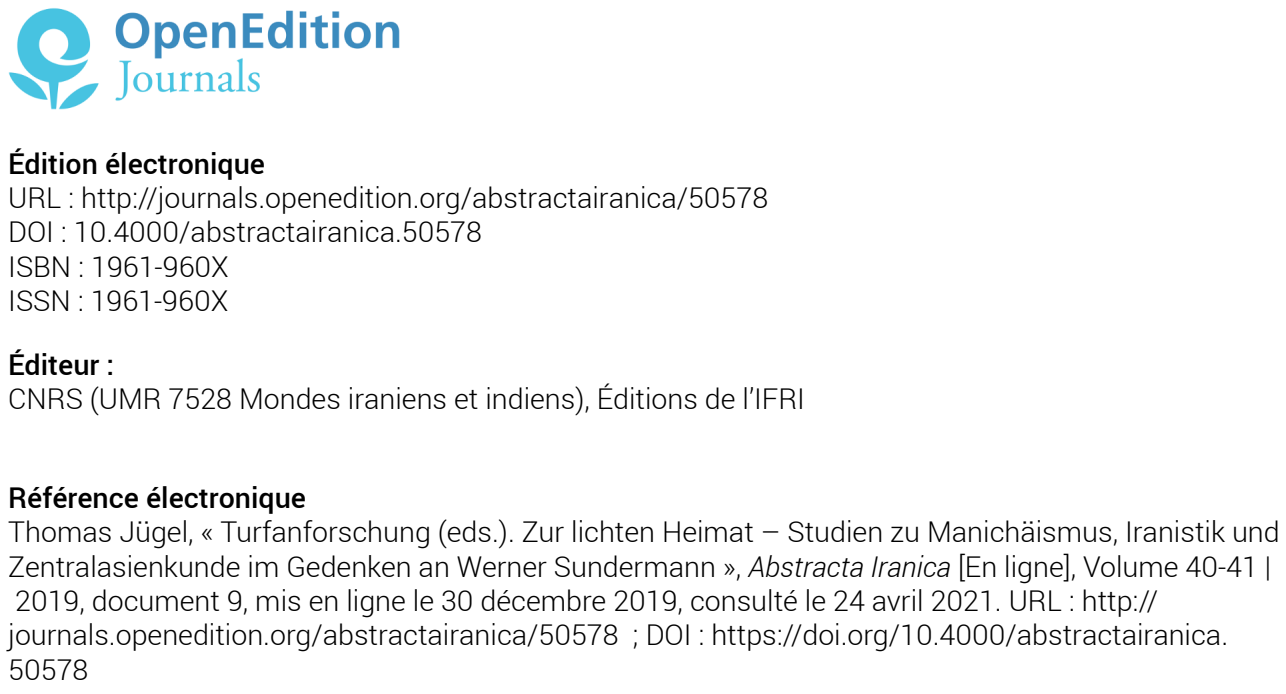

Ce document a été généré automatiquement le 24 avril 2021

Tous droits réservés 


\title{
Turfanforschung (eds.). Zur lichten Heimat - Studien zu Manichäismus, Iranistik und Zentralasienkunde im Gedenken an Werner Sundermann
}

\author{
Thomas Jügel
}

\section{RÉFÉRENCE}

Turfanforschung (eds.). Zur lichten Heimat - Studien zu Manichäismus, Iranistik und Zentralasienkunde im Gedenken an Werner Sundermann. Wiesbaden: Harrassowitz, 2017, XII+754 p. (Iranica 25)

1 This enormous memorial volume of 754 pages contains 56 contributions in English (40x), French (2x), German (12x), and Russian (2x). They cover all aspects of Turfan studies, notably editions, palaeographic and philological work as well as comparative and interpretative studies of various religions (particularly Manichaean and Buddhism) and several languages (Iranic: especially Middle Persian, Parthian, and Sogdian; Turkic: especially Uighur; Tocharian; Chinese; Coptic; Greek and others). The volume is introduced by three contributions that put the commemorated at their heart, and many authors include a personal salute in their papers, which reveal the high appreciation they felt for Werner Sundermann as a colleague and friend.

2 It is impossible to write a classical review of a volume of such dimensions that would do justice to its richness. Instead of listing the contributions - this information is easily available in the Table of contents on the publisher's homepage - or focusing on a few selected contributions, I have decided to procure an index to this volume that lists the text sources mentioned in this book. Due to space limitations, this index is published at https://halshs.archives-ouvertes.fr/halshs-02417588. Here I will restrict myself to 
mentioning a few selected editions, often the first publication of the text in question, including a facsimile, transliteration / transcription and translation.

Decorated silver Pyxis with Bactrian inscription in comparison to several coins, pp. 125-136 with photos of the Pyxis and facsimiles, by Harry Falk and Nicholas SimsWilliams.

4 Khotanese fragments of the Sanghātasūtra KS 6 and KS 8, pp.374-376 with facsimiles, by Mauro Maggi.

5 Middle Persian Manichaean fragment "Oldenburg" (fond 208, opis 1, delo 130, 1.1) of Oldenburg Archives in St. Petersburg, p.66 with a facsimile, and the fragments S 14a [=SI $\mathrm{O} / 71$ ] and S 14b [=SI O/72], pp.68-69 with facsimiles, by Olga M. Chunakova. The first Middle Persian Manichaean fragment from Iran "Shiraz fragment", pp.642-647, with photos and facsimiles pp.639-641 \& 643 \& 645, by Mohammad Shokri-Foumeshi. Middle Persian Barm-e Delak inscription pp.105-108 with a drawn facsimile, by Desmond Durkin-Meisterernst. A number of passages from the Middle Persian Dēnkard Book 3, pp.243-250, by Judith Josephson. Middle Persian text Tab.18 of the Tabaristān collection, pp.363-364, by Maria Macuch. Middle Persian, Parthian and Sogdian manuscripts M114 I R 5-V 8, M114 II, M776, M625a, M266 R ii, M4a I R 1-7, M6451 [=T II D 406a], pp.445-452. by Enrico Morano.

Parthian elements in the Chinese Manichaean Xiapu text, pp.721-724 \& 728 \& 732-734, with the Parthian original M1367 and an Old Uighur translation MIK III 200 I, pp. 726-727, by Yutaka Yoshida.

7 Sogdian fragment So 10239(4)r, p.600, with a facsimile p.599 (recto and verso) and fragment Mainz 154, p.602, with facsimile p.603, by Christiane Reck.

Old Uighur fragment Ch/U 6114 [=T III M 173/139], pp.254-256, by Yukiyo Kasai. Old Uighur account book ${ }^{*} \mathrm{U} 9271$, pp.410-412, by Dai Matsui. Old Uighur fragments $\mathrm{Ch} / \mathrm{U}$ $6916 \mathrm{v}$ and $\mathrm{Ch} / \mathrm{U} 6620 \mathrm{v}$, pp.586-588, with facsimile p.584, by Simone-Christiane Raschmann. Old Uighur fragment BD 14741 L, pp.713-714, by Abdurishid Yakup.

Tumshuqese documents TUMXUQ 001-004, pp.455-473, with facsimiles pp.477-482, by Hirotoshi Ogihara and Ching Chao-Jung.

\section{AUTEURS}

THOMAS JÜGEL

Allemagne 